\title{
EFFECT OF TOTAL RESECTION OF SMALL INTESTINE ON GASTRIN-RELEASING PEPTIDE (GRP)-STIMULATED PANCREATIC SECRETION IN ANESTHETIZED RABBITS
}

\author{
Tadao Manabe, Eiji Kit, Gakuji Ohshio, Tetsuya Hirano, Kenichiro Yamaki, Atsushi \\ Nonaka, Koichiro Tamura and Takayoshi Tobe \\ First Department of Surgery, Faculty of Medicine, Kyoto University, Shogoin-Kawaracho, Sakyoku, Kyoto \\ 606, Japan
}

\begin{abstract}
The effect of the total resection of the small intestine with or without truncal vagotomy, to exclude the involvement of cholecystokinin (CCK) and secretagogues from the small intestine, on porcine gastrin-releasing peptide (pGRP)-stimulated exocrine pancreatic secretion was studied in anesthetized rabbits. Following the administration of pGRP at $1 \mu \mathrm{g} / \mathrm{kg} / 1 \mathrm{~h}$, the pancreatic volume was not significantly altered in any of the groups throughout the observation period. The peak increment in pancreatic protein output in response to pGRP was about 20 times higher than the basal level in each group. Neither resection of the small intestine nor the resection of the small intestine with a truncal vagotomy significantly altered the pancreatic protein, amylase and lipase output in response to pGRP. These results clearly show that, in anesthetized rabbits, pGRP directly stimulates pancreatic protein and enzyme secretion, though the possibility remains that pGRP additionally exerts its stimulation on the pancreas being mediated by CCK.
\end{abstract}

Gastrin-releasing peptide (GRP), initially isolated from porcine non-antral gastric and intestinal tissues by McDonald et al. $(16,17)$ has a similarity with bombesin in its amino acid sequence of the $\mathrm{C}$-terminal portion and is considered to be a mammalian analog of bombesin $(4,17)$. Beside its effect on gastrin release and on gastric juice secretion, GRP has a powerful stimulant effect on pancreatic enzyme secretion. Since bombesin is reported to stimulate the release of cholecystokinin (CCK), the stimulant effect of bombesin or GRP on exocrine pancreatic secretion is considered to be due largely to the release of CCK $(12,20)$. However, there are some controversies concerning the stimulant mechanism of the exocrine pancreas by GRP. Although GRP as well as bombesin possess a direct stimulant effect on the release of amylase from isolated pancreatic acini $(8,18)$, it is not clear how CCK participates in GRP-induced exocrine pancreatic stimulation. This study was conducted to determine the influence of the upper intestine, which is a major site of $\mathrm{CCK}$ production, on the porcine gastrin-releasing peptide (pGRP)-induced pancreatic secretion in anesthetized rabbits.

\section{MATERIALS AND METHODS}

White male rabbits weighing 2.6 to $3.0 \mathrm{~kg}$ were divided into three groups. Group $1(n=4)$ was a control group. Following a 24 -h fast, a laparotomy was performed under general anesthesia with pentobarbital $(25 \mathrm{mg} / \mathrm{kg})$. The pylorus was ligated and a silicon tube was inserted so as to draw off gastric juice, preventing the flow of gastric juice into the duo- 

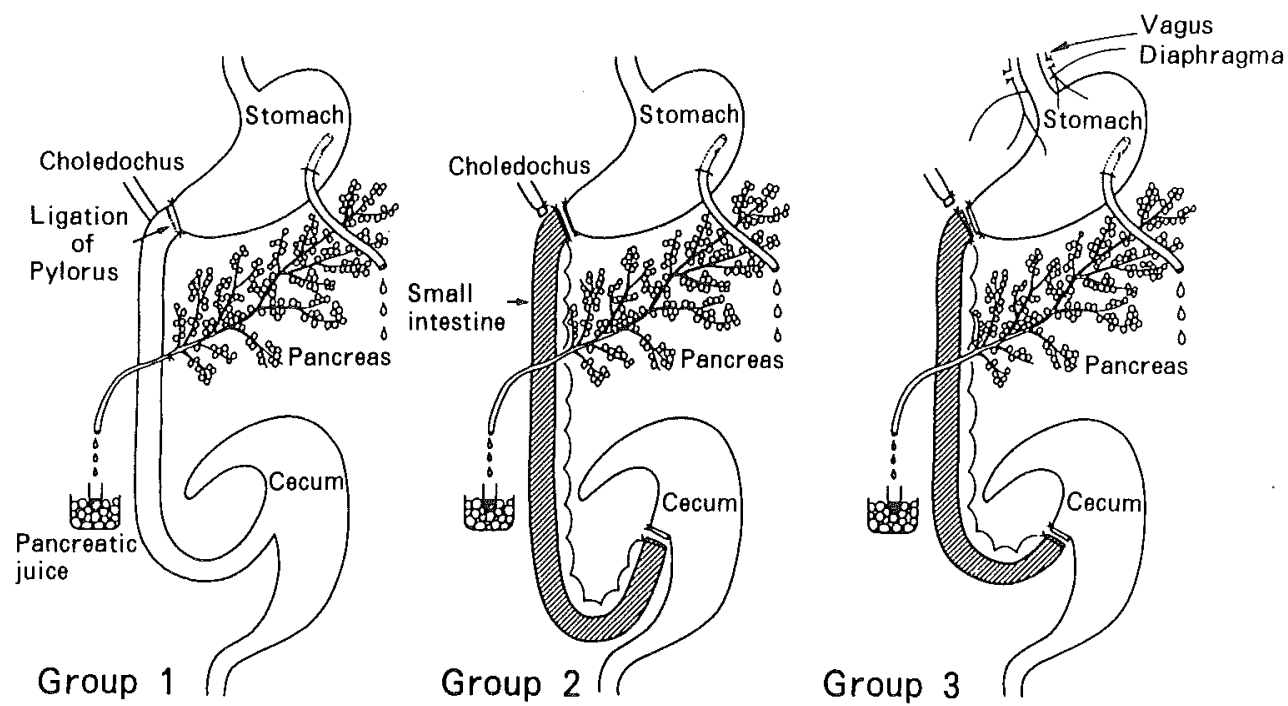

Fig. 1 Operative procedures in groups 1, 2 and 3

denum. A polyethylene tube (PE 50) was inserted into the pancreatic duct adjacent to the opening into the duodenum, and the outflowing pancreatic juice was collected into a cold microtube. Group $2(n=4)$ had their entire small intestine resected. Following the cannulation of the pancreatic duct with a polyethylene tube, the entire small intestine, from the pylorus to the ileal end, was resected. The common bile duct was ligated and cut. Group $3(n=4)$ had their entire small intestine resected followed by a truncal vagotomy. After the entire small intestine was removed, a bilateral transthoracic truncal vagotomy was performed (Fig. 1). In each animal, tests were started $2 \mathrm{~h}$ after the operation when the pancreatic juice flow had been stabilized. Each test consisted of a $30 \mathrm{~min}$ basal period followed by $1 \mathrm{~h}$ period of stimulation with pGRP at $1 \mu \mathrm{g} / \mathrm{kg} / \mathrm{h}$ which is the submaximum stimulation dose for pancreatic enzyme secretion. Pancreatic juice samples were taken at $30 \mathrm{~min}$ intervals from $30 \mathrm{~min}$ before to $3 \mathrm{~h}$ after the administration of pGRP into microtubes chilled in ice, and stored below $-20^{\circ} \mathrm{C}$ till assay. The juice volume and the protein, amylase and lipase output were measured. Protein was measured by the method of Lowry et al. (13). Amylase was measured by a modified method of Ceska et al. (5), and lipase was measured spectrophotometrically using BALtributyrate as a substrate (11). Synthesized
pGRP was a gift from Professor H. Yajima (21).

Comparisons between pairs of experimental conditions were made using a paired $t$-test. Differences in $P$ values of less than 0.05 were considered significant.

\section{RESULTS}

The basal pancreatic secretory volume was $82.8 \pm 13.0 \mu 1 / \mathrm{kg} / 30 \mathrm{~min}$ in group $1,60.5 \pm 13.1$ $\mu 1 / \mathrm{kg} / 30 \mathrm{~min}$ in group 2 and $63.7 \pm 16.1 \mu \mathrm{l} / \mathrm{kg} /$ $30 \mathrm{~min}$ in group 3 . In each group, throughout the observation period, the volume was not significantly altered by the infusion of pGRP. There was no significant difference in the change in pancreatic juice flow among the three groups (Fig. 2). Basal protein output was $0.29 \pm 0.07 \mathrm{mg} / \mathrm{kg} / 30 \mathrm{~min}$ in group $1,0.20 \pm$ $0.01 \mathrm{mg} / \mathrm{kg} / 30 \mathrm{~min}$ in group 2 , and $0.24 \pm$ $0.03 \mathrm{mg} / \mathrm{kg} / 30 \mathrm{~min}$ in group 3 . These values were not significantly different from each other. In group 1, following the administration of pGRP at $1 \mu \mathrm{g} / \mathrm{kg} / 1 \mathrm{~h}$, the protein output was markedly increased and reached a maximum of $6.24 \pm 0.48 \mathrm{mg} / \mathrm{kg} / 30 \mathrm{~min}$. After finishing the administration of pGRP, the protein output was gradually decreased. In both groups 2 and 3 , the protein output was markedly increased following the administration of pGRP in a similar fashion as in group 1 (Fig. $3)$. The cumulative 3 -h protein output follow- 


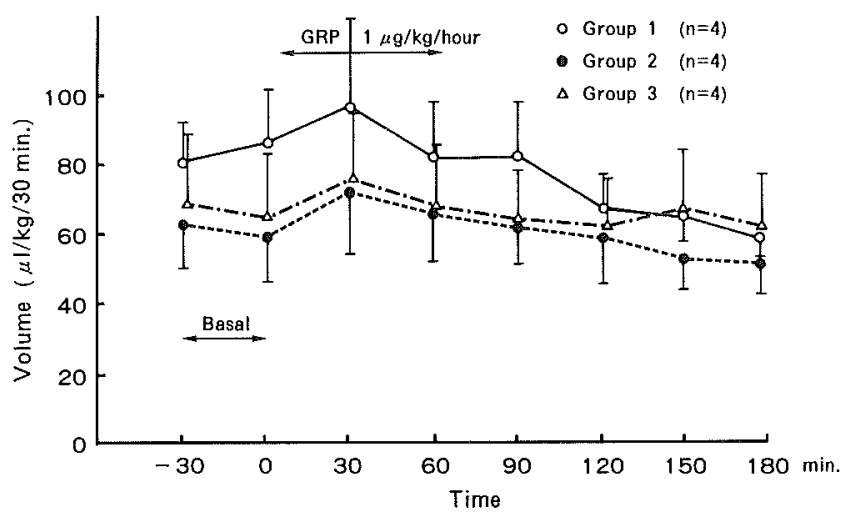

Fig. 2 Effects of pGRP $(1 \mu \mathrm{g} / \mathrm{kg} / \mathrm{h})$ on the volume of pancreatic juice in group 1 (control), group 2 (resection of small intestine) and group 3 (resection of small intestine with truncal vagotomy) in anesthetized rabbits. Values are mean \pm SEM. There was no significant difference in the volume of pancreatic juice among the three groups.

ing the administration of pGRP at $1 \mu \mathrm{g} / \mathrm{kg} / \mathrm{h}$ was $19.3 \pm 2.9 \mathrm{mg} / \mathrm{kg} / 3 \mathrm{~h}$ in group $1,15.7 \pm$ $2.4 \mathrm{mg} / \mathrm{kg} / 3 \mathrm{~h}$ in group 2 and $17.7 \pm 1.8 \mathrm{mg} /$ $\mathrm{kg} / 3 \mathrm{~h}$ in group 3 . There were no significant differences in the changes in protein output among the three groups (Fig. 4).

Similarly, the amylase and lipase outputs increased markedly following the administration of pGRP (Fig. 4). Basal and cumulative amylase outputs in response to pGRP were $27.7 \pm 9.5 \mathrm{IU} / \mathrm{kg} / 30 \mathrm{~min}$ and $2,460 \pm 540 \mathrm{IU} /$ $\mathrm{kg} / 3 \mathrm{~h}$ respectively in group $1,21.7 \pm 3.5 \mathrm{IU} /$ $\mathrm{kg} / 30 \mathrm{~min}$ and $1,850 \pm 230 \mathrm{IU} / \mathrm{kg} / 3 \mathrm{~h}$ in group 2 , and $20.5 \pm 1.8 \mathrm{IU} / \mathrm{kg} / 30 \mathrm{~min}$ and $2,400 \pm 440$ $\mathrm{IU} / \mathrm{kg} / 3 \mathrm{~h}$ in group 3 . Basal and cumulative lipase outputs were $6.60 \pm 2.15 \mathrm{IU} / \mathrm{kg} / 30 \mathrm{~min}$ and $704 \pm 119 \mathrm{IU} / \mathrm{kg} / 3 \mathrm{~h}$ respectively in group $1,4.15 \pm 0.38 \mathrm{IU} / \mathrm{kg} / 30 \mathrm{~min}$ and $603 \pm 122 \mathrm{IU} /$ $\mathrm{kg} / 3 \mathrm{~h}$ in group 2, and $4.10 \pm 1.08 \mathrm{IU} / \mathrm{kg} /$ $30 \mathrm{~min}$ and $659 \pm 57 \mathrm{IU} / \mathrm{kg} / 3 \mathrm{~h}$ in group 3 . There were no significant differences in basal and cumulative outputs of amylase and lipase among the three groups (Fig. 4).

\section{DISCUSSION}

In the present study with anesthetized rabbits, pGRP at a dose of $1 \mu \mathrm{g} / \mathrm{kg} / \mathrm{h}$, which is a submaximum dose for the stimulation of the protein output, significantly stimulated the pancreatic protein, amylase and lipase output without affecting the pancreactic juice flow.
This stimulatory effect of pGRP on the section of pancreatic protein and enzymes has been claimed to occur via a mechanism similar to that of bombesin $(1,6,7,20)$. Since bombesin is known to stimulate pancreatic enzyme secretion as well as gallbladder contraction $(11,13)$, this action has been considered to occur through CCK. Jansen and Lamers (9) observed in humans that bombesin resulted in a significant increase in plasma CCK. However, in our recent study in rabbits, duodenal acidification augmented the pancreatic protein secretion as well as the juice volume and the bicarbonate secretion in response to GRP (14). pGRP has also been shown to highly stimulate the isolated pancreas $(8,14,18)$. These results show that pGRP possesses a direct as well as an indirect effect through substances from the intestinal mucosa, although the exact mechanism is not yet known. To clarify whether or not $p$ GRP-induced stimulation of the pancreatic enzyme secretion is mediated by CCK or by other secretagogues from the intestine, the effect of the total resection of the small intestine on pGRP-stimulated pancreatic enzyme secretion was examined.

The present study provides the following conclusion; neither the total resection of the small intestine nor the total resection of the small intestine with a truncal vagotomy significantly altered the pancreatic protein and enzyme secretion in response to exogenous 


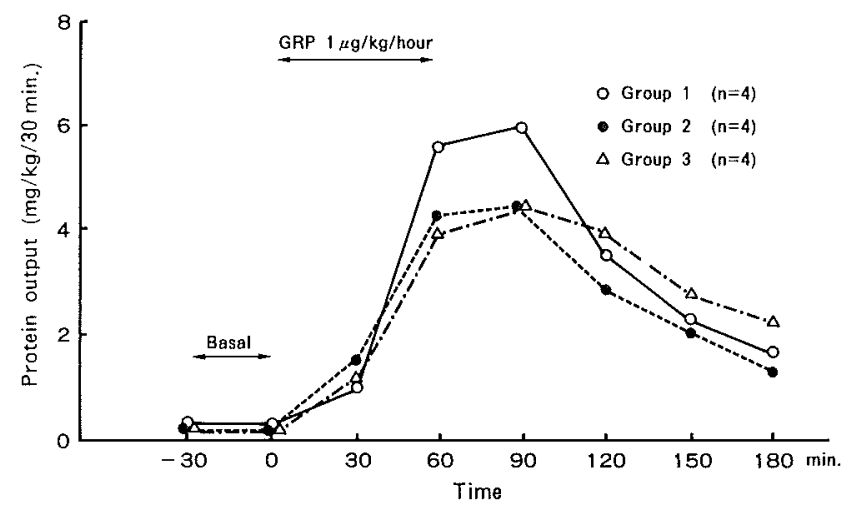

Fig. 3 Effect of pGRP $(1 \mu \mathrm{g} / \mathrm{kg} / \mathrm{h})$ on protein output in rabbit groups 1,2 and 3. Mean values are given. Changes in protein output are seen in three groups.
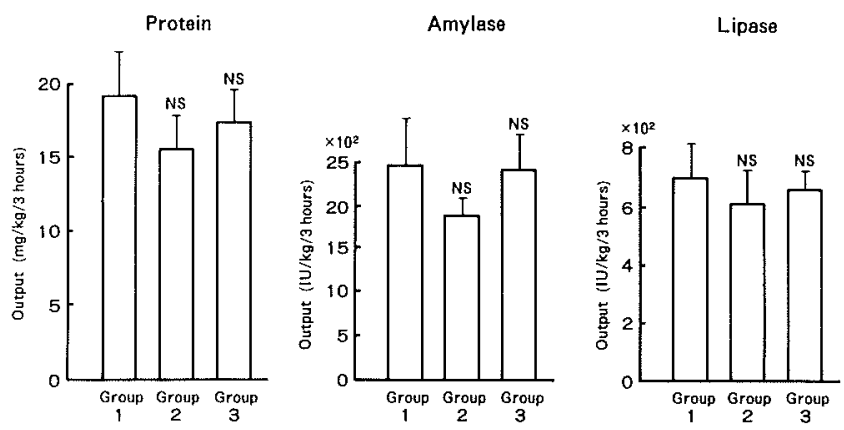

Fig. 4 Effects of pGRP $(1 \mu \mathrm{g} / \mathrm{kg} / \mathrm{h})$ on the cumulative protein, amylase and lipase outputs in rabbit groups 1,2 and 3 . Each value is the mean \pm SEM of four separate experiments. There were no significant differences in the basal and the pGRP-stimulated outputs among the three groups.

pGRP. These results clearly indicate that pGRP has a strong direct effect on pancreatic protein and enzyme secretion. In addition, the present study has shown that in the anesthetized rabbits, the action of pGRP is not vagusdependent, although the influence of anesthetic agent can not be disregarded $(2,3,19)$.

Acinar cells are reported to have receptors for bombesin which act to increase the calcium outflow and to accumulate cyclic GMP rather than cyclic AMP (10). Shibuya et al. (18) reported that secretory response to GRP may be caused by the extracellular and intracellular $\mathrm{Ca}^{2+}$. The $\mathrm{Na}^{+}$and the $\mathrm{K}^{+}$concentration in the extracellular environment is also noted to cause a secretory response to GRP (18). Since bombesin does not augment the activity of cyclic AMP as does CCK (15), pGRP, like bombesin, could act directly on acinar cells without the participation of CCK.

These findings suggest that the major action of pGRP on the secretion of pancreatic protein and enzymes in anesthetized rabbits is direct, though the possibility remains that pGRP additionally exerts its stimulation on the pancreas being mediated by CCK or secretagogues derived from the small intestine.

This investigation was partly supported by a grant (Scientific Research B-62480282) from the Ministry of Education, Science and Culture, and a grant from the Ministry of Health and Welfare, Japan.

Received for publication 17 April 1989; and in revised form 2 June 1989 


\section{REFERENCES}

1. Basso N., Giri S., Improta G., Lezoche E. Melchiorri P., Percoco M. and Speranza V. (1975) External pancreatic secretion after bombesin infusion in man. Gut 16, 994-998

2. Ben-ARi G., Rudick J., Kark A. E. and DreilING D. A. (1969) Effects of anesthesia on pancreatic exocrine secretion. Ann. Surg. 170, 747752

3. Boden G., Shore L. S., Wilson R. M., EssaKoumar N. and Landor J. H. (1977) Effects of $\mathrm{Na}$ pentobarbital anesthesia on serum secretion and exocrine pancreatic secretion. Horm. Metab. Res. 9, 123-127

4. Brown M., Märki W. and Rivier J. (1980) Is gastrin releasing peptide mammalian bombesin? Life Sci. 27, 125-128

5. Ceska M., Birath K. and Brown B. (1969) A new and rapid method for the clinical determination of $\alpha$-amylase activities in human serum and urine optimal conditions. Clin. Chim. Acta 26, 437-444

6. Erspamer V., Improta G., Melchiorri P. and Sopranzi N. (1974) Evidence of cholecystokinin release by bombesin in the dog. Brit. $J$. Pharmacol. 52, 227-232

7. Ghatei M. A., Jung R. T., Stevenson J. C., Hillyard C. J., Adrian T. E., Lee Y. C., Christofides N. D., Sarson D. L., Mashiter K., Macintyre I. and Bloom S. R. (1982) Bombesin: Action on gut hormones and calcium in man. J. Clin. Endocinol. Metab. 54, 980-985

8. Iwamoto Y., NaKamura R. and AKanuma Y. (1983) Effects of porcine gastrin-releasing peptide on amylase release, 2-deoxyglucose uptake, and $a$-aminoisobutyric acid uptake in mouse pancreatic acini. Endocrinology 113, 21062112

9. JANSEN J. B. M. J. and LAMERS C. B. H. W. (1983) Molecular forms of cholecystokinin in human plasma during infusion of bombesin. Life Sci. 33, 2197-2205

10. Jensen R. T., Moody T., Pert C., River J. E. and GARDNER J. D. (1978) Interaction of bombesin and litorin with specific membrane receptors on pancreatic acinar cells. Proc. Natl. Acad. Sci. USA 75, 6139-6143

11. Kurooka S., Okamoto S. and Hashimoto M. (1977) A novel and simple colorimetric assay for human serum lipase. J. Biochem. 81, 361-
369

12. Lilja P., Greeley G. H. and Thompson J. C. (1984) Pancreatic exocrine secretion. Release of gastrin and cholecystokinin in response to bombesin in pigs. Arch. Surg. 119, 825-828

13. Lowry O. H., Rosebrough N. J., Farr A. L. and RANDALL R. J. (1951) Protein measurement with the Folin phenol reagent. J. Biol. Chem. 193, 265-275

14. Manabe T., Kil E., Ohshio G., Hirano T., YAMaki K., Nonaka A., Tamura K, and Tobe T. (1989) Effect of gastrin releasing peptide on pancreatic exocrine secretion in the anesthetized rabbit. Surg. Res. Comm. (in press)

15. May R. J., Conlon T. P., Erspamer V. and GaRDNER J. D. (1978) Actions of peptides isolated from amphibian skin on pancreatic acinar cells. Amer. J. Physiol. 235, E112-E118

16. McDonald T. J., Jörnvall H., Nilsson G., VAGNe M., Ghatei M., Bloom S. R. and Mutt V. (1979) Characterization of a gastrin releasing peptide from porcine non-antral gastric tissue. Biochem. Biophys. Res. Commun. 90, 227-233

17. McDonald T. J., Nilsson G., Vagne M., Ghatei M., Bloom S. R. and Mutt V. (1978) A gastrin releasing peptide from the porcine nonantral gastric tissue. Gut 19, 767-774

18. Shibuya I., Kanno T., Mochizliki T. and YanaiHARA N. (1986) Secretory and redox response to GRP and bombesin in various ionic environments in the solated perfused rat pancreas. Biomedical Res. 7, Suppl. 2, 113-120

19. Singer M. V., Niebel W., Lamers C., Becker S., Vesper J., Hartmann W., Diemel J. and Goebell H. (1981) Effects of truncal vagotomy and antrectomy on bombesin-stimulated pancreatic secretion, release of gastrin, and pancreatic polypeptide in the anesthetized $\mathrm{dog}$. Digest. Dis. Sci. 26, 871-877

20. Wood S. M., Jung R. T., Webster J. D., Ghatei M. A., Adrian T. E., Yanaihara N., YanaiHARA C. and Bloom S. R. (1983) The effect of the mammalian neuropeptide, gastrin-releasing peptide (GRP), on gastrointestinal and pancreatic hormone secretion in man. Clin. Sci. $\mathbf{6 5}$, 365-371

21. Yajima H., Akaji K., Fujil N., Moriga M., Aono M. and TaKagi A. (1980) A heptacosapeptide amide corresponding to the entire amino acid sequence of gastrin releasing peptide. Chem. Pharm. Bull. 28, 2276-2278 